\title{
市街地風環境評価の課題と「都市の風影響評価研究会」の取り組み Issues of Evaluation of Pedestrian Wind Environment and Activities of the Study Group of Wind Effect on Urban Environment
}

\author{
富永禎秀* \\ Yoshihide TOMINAGA
}

\section{1.はじめに}

高層建築物が各地に建て始められ，高層建物周辺で発 生するビル風が，「風害」としてマスコミ等で扱われるよ うになってから, 約 50 年が経とうとしている。その間の 社会や行政, 学会等の動向については, 本特集中の原稿 1)において年譜として整理されている。年譜に見られるよ うに，市街地の風環境の問題に関して，本学会が果たし てきた役割は小さくないものの,「行政や一般住民の理解 が不可欠であり技術論だけでは完結しにくい」,「社会や 生活様式の変化といった時代背景の影響を強く受ける」 といった市街地風環境特有の性質もあり, 課題解決への プロセスが複雑な面もある。

日本風工学会・都市の風影響評価研究会は, 都市にお いて風が建物や環境，生活一及ぼす影響を総合的にかつ 適切に評価する新しいフレームについて議論することを 目的として，2005 年に設置され，これまで活動を進めて きた。本特集は, これまでの研究会の活動を総括すると ともに, 現状の市街地風環境の課題を整理し, 今後の展 望を明らかにすることを目的としている。

本稿では, 特集のイントロダクションとして, 市街地 風環境を「予測」「評価」「制御」の3つのステップに分 けて，それぞれの課題を概説し，それに対する本研究会 の成果，そして残された課題を示したい。

\section{2. 市街地風環境の予測における課題}

(1) CFD の利用拡大
コンピュータの高速化及び流体解析ソフトの普及に伴 い, CFD (Computational Fluid Dynamics : 数值流体力学) は, 流体力学の強力な解析ツールとして, 工学の様々な 分野で用いられるようになってきた。CFD は風洞実験の ような特殊な実験装置を必要とせず，またかかる時間や 材料費，労力等を考えると，コス卜面で大いに有利であ ることが期待される。また風洞実験では限られた測定点 での風速情報しか得られないのに対し，CFD では詳細か つ三次元的な風速の空間分布性状が把握できるというメ リットがある。すなわち風洞実験では捉え切れない風環 境上の問題点を CFD では捉えられたり, より効果的な対 策を計画できる可能性がある。また風洞実験には実験の 不確かさ (計測器の誤差, 偶然誤差, センサ一設置位置 の誤差等）が避けられないが，CFD ではこのような不確 かさが介在する要因が少ない。

一方，CFD においては，シミュレーション結果が，計 算で用いる数值パラメータや境界条件に強く依存するこ とに注意しなくてはならない。すなわち, CFD の精度や 不確かさに細心の注意を払う必要がある。そのためには, 各種パラメータやグリッド分割, 境界条件の感度解析及 び実験結果を用いての検証が極めて重要である。CFD の 解析結果に影響を及ぼす各種の数值パラメータや境界条 件について，その適切な与え方の目安を与えるガイドラ インが様々な学会や分野において提案されている。市街 地風環境の問題に対しては, 2007 年に日本建築学会から CFD を適切に利用寸るための注意点や解析精度の検証方

\footnotetext{
* 新潟工科大学 教授 tominaga@abe.niit.ac.jp
} Professor, Niigata Institute of Technology 
法について解説したガイドブック「流体数值解析による 市街地風環境の予測・評価ガイドブックー検証用データ ベース付きー」が刊行された ${ }^{2}$ 。このガイドブック及び CFD 適用のためのガイドライン ${ }^{3)}$ は, 国内外で広く引用 されているが，基本的にアンサンブル平均された流れ場 を解析対象とする RANS (Reynolds-Averaged Navier-Stokes equations）モデルの強風問題への適用を対象としており, 濃度・温度などの拡散問題や Large Eddy Simulation (LES) 等の非定常解析の風環境問題への適用については, 殆ど 触れられていなかった。これらのCFD の適用に対寸る最 近のユーザの関心の高まりを踏まえたガイドラインの拡 張のための検討が現在行われている4)。

(2) 最大瞬間風速の予測

現在のところ，実務的には，風洞実験及び数值解析と もに, 平均風速が予測される場合が殆どである。従って, 後述する「日最大瞬間風速の超過確率に基づく評価尺度」 5)のように最大瞬間風速を評価したい場合, ガストファク

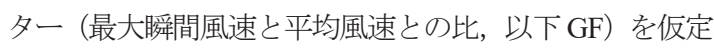
することが便法として行われてきた。しかしながら，最 近では, 計測器の精巧化（熱線風速計や PIV など）や計 算能力の向上 (LES などの非定常かつ高分解能の CFD) によって, 最大瞬間風速を評価すること自体は実用的に も不可能ではない。最大瞬間風速を直接予測することが できれば, GF に寄らずに, 最大瞬間風速が評価できるこ とになる。しかしながら, 風洞実験や非定常数值解析に おいて, 風環境評価に適用できる最大瞬間風速を得るた めの評価時間, 平均時間をどのように取ればよいか, 十 分なコンセンサスは得られてはおらず，さらなる検討が 必要と思われる。

\section{(3) 標準気象データの整備}

風洞実験であっても CFD であっても，ビル風評価に用 いるいわゆる上空風の気象データは, 建設地に最も近い 気象観測所（気象官署やアメダス観測点）等で得られた 観測值が用いられる。しかし, よく知られているように, 気象観測所で観測されたデータは周辺の建築物や地表面 近くの地形の影響を受けている場合が多く, 周辺の状況 なども考慮して, 利用可能な観測データの中から取捨選 択し，採用しているのが実情である。当然のことながら， 異なる上空風データを用いれば，風環境評価結果も異な る。すなわち, どの上空風気象データを用いるかは, 結 果の信頼性に大きな影響を及ぼすが，必ずしも明確なル 一ルがある訳ではなく, 評価の客観性の面で問題がある。 そのような課題を踏まえ, 本研究会の活動の一環として, 気象モデルを用いて，地表面近くの地物の影響を受けな
い都市上空風気象データの整備を検討したのっこうしたデ 一タを用いることによって, 風環境評価の一般性や公平 性が向上するものと期待される。

\section{3．市街地風環境の評価における課題 \\ （1）風環境評価尺度}

国内外でこれまでに提案されている風環境の評価尺度 は, 文献 7 に詳細にまとめられている。高層建物周辺の

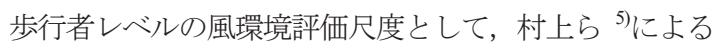

「日最大瞬間風速の超過確率に基づく評価尺度」及び風 工学研究所による「10 分間平均風速の発生頻度に基づく 評価尺度」 ${ }^{8}$ がよく用いられている。

村上らの評価尺度は，高層建物周辺で実施した詳細な 風の実測と同時に実施した市街地の風環境状態について のモニタ一調查から，(1)風速と一日の風環境の良し悪し の関係，(2)風速と発生する現象の関係，(3強風と判断さ れる風環境レベルを示寸日数の年間に許容される限度, を明らかにし, 日最大瞬間風速の許容頻度を規定したも のである。

風工学研究所の評価尺度も同様であるが，これらの評 価尺度は, ランク分けされた風の予測される出現頻度に よって判定される。確率による評価は住民にとっては理 解し難く, 結果的にビル風問題の解決を困難にしている 場合がある。最近では，より住民の理解のしや寸い風環 境の評価方法が，スマートフォンやSNS といったツール を活用した住民参加型の調査に基づいて検討されている 9,10)。またこうした新しいツールを活用した都市の暑さ・ 涼しさを把握しようとする試みも行われている ${ }^{11}$ 。一方, 既存の評価尺度は，日常的な快・不快に主眼があるのに 対して, 歩行者の転倒等の事故に着目した風安全指標が 提案されている ${ }^{12)}$ 。

(2) ガストファクター $\mathrm{GF}$ の設定

前述の通り, 現状の実務における風洞実験または数值 シミュレーションでは，ほとんどの場合，瞬間風速では なく平均風速を求めている。そのため, 最大瞬間風速を 求めたい場合, GF（最大瞬間風速と平均風速との比）が 必要となる。GF は, 地表面近くでは一般に 1.5 2.5 の值 を採るとされている ${ }^{5)}$ 。この範囲は非常に広く, 評価結果 に大きい影響を及ぼすが，適切にその值を決定すること は難しく, 評価尺度の分かりにくさの要因の一つとなっ ていた。都市の風影響評価研究会では, この評価尺度に おいて, 日最大平均風速と日最大瞬間風速を関係づける ために必要となる GF の評価式を提案した ${ }^{13)}$ 。

(3) 環境影響評価制度における「風害」の扱い 
本特集中の原稿 ${ }^{14)}$ で報告されている通り，全国の環境 影響評価条例を有する自治体のうちの約 $1 / 3$ で市街地風 環境（ビル風，風害）に関寸る評価項目がある。実際に この制度が適用される物件を有している自治体数は，さ らにその $1 / 3$ 程度と多くはない。自治体の担当者へのアン ケート結果を見ると，全体的には現行の風環境の影響評 価の体系に大きな問題はないとも読み取れるが，一方， いくつかの課題も指摘されている。学術的な精度向上を 図るだけでなく, 学会の研究成果等を行政や住民に対し て分かりやすく情報発信していく工夫も一層必要と思わ れる。

\section{4. 市街地風環境の制御における課題}

風環境を事前に予測・評価した結果（あるいは建物建 設後に実際に観測した結果), 建築物建設により風環境が 悪化し，風による障害が生じる（あるいは生じている） と判断されたときは，強風を防除するための対策，すな わち, 防風対策を講ずる必要がある。

建物の配置や形状自体を変更すれば（1次的対策と呼 ばれる)，より積極的に風を “制御”することによって大 きな効果が期待できるが，一般に建物の形状，配置など は, ビル風害の面からのみ決定されるものではなく,さ らに時間的・経済的な制約もあり実際には容易でない場 合が多い。また既に建設された建物の場合，このような 対策を行うことは困難である。その結果, 植栽やフェン ス等の遮へい物を設置して風を弱める 2 次的な対策が行 われる場合が多い。

ただし近年，CFD を利用することによって，建物配置 や形状の変更が周辺風環境に及ぼす影響を調べることは, 以前と比べて, 格段に短時間かつ高精度に行えるように なってきている。建物計画の初期段階において，1次的 対策として積極的に周辺風環境に配慮されることが期待 される。一方，2次的対策である植栽やフェンスを CFD においてどのようにモデル化するかについては, 必ずし もコンセンサスが得られている訳ではない。これらのモ デル化に際しては, 抗力を規定するパラメータの設定が 風速の低減効果に大きな影響を持つため, 染意的に扱わ れる可能性が無いとは言えない。適正な使用上のガイド ライン等の整備が求められる。

\section{5。まとめ}

本特集号では，上記で述べたような市街地風環境の予 測・評価における課題を改めて整理することを目的とし て, 最近, 都市の風影響評価研究会で検討した成果を,
以下の特集記事として報告する。

1) ビル風問題の年譜 ${ }^{1)}$

ビル風が問題となって以降, 約 50 年間の出来事や研究, 資料等を調べた結果を年譜として示す。

$2 ）$ 各自治体のビル風の環境影響評価に関する条例の調 查 ${ }^{14)}$

自治体の環境影響評価担当者へのアンケート調査, イ ンターネットを利用した制度の現状調查によって, 現在 の我が国における風環境（ビル風）に関する環境影響評 価（アセスメント）の実態を整理した結果を報告する。

3 ）住民参加型の風環境調查事例の紹介 ${ }^{15}$

これまでに行われている，住民の風に対する感じ方や 意識を調查した研究成果をレビューする。

4) 日本ヒートアイランド学会の「暑さマップ」の取り 組みについて ${ }^{16}$

日本ヒートアイランド学会が開発した，スマートフォ ンでその場の暑さや涼しさなどの感覚を入力し Google Map 上に視覚的に結果が表示されるアプリ，及びそれを 活用した取り組みについて紹介する。

謝辞

都市の風影響評価研究会に, これまで参加された方々 は以下の通りである (五十音順, 敬称略)。委員の皆様の ご協力に深く感謝するものである。

飯塚 悟 (名古屋大学)

石原 孟 (東京大学)

伊藤 真二（(株）鴻池組 技術研究所）

岡田 創（(株）泉創建エンジニアリング）

片岡 浩人（(株）大林組 技術研究所）

小見 崇之（東急建設（株）技術研究所）

喜々津 仁密（当時: 建築研究所/現在 国土交通省国

土技術政策総合研究所)

作田 美知子 (三井住友建設 (株) 技術研究開発本部) 佐々木 澄（清水建設（株）技術研究所）

白澤 多一 (大妻女子大学)

竹見 哲也（京都大学 防災研究所）

東城 理恵 ((独) 都市再生機構 技術・コス卜管理部技 術研究所)

富永 禎秀（新潟工科大学）

中村 良平 (大成建設 (株) 技術センター)

西村 宏昭 (京都大学)

野田 博（当時: 三井住友建設（株）技術研究所／現在 近畿大学)

林 宏典（(財) 日本気象協会 調査部) 
林田 宏二 (当時: 鹿島建設 (株) 技術研究所／現在 同 環境本部)

藤井 邦雄（(株）風環境リサーチ）

宮下 康一（(株）風工学研究所)

山中 徹（鹿島建設（株）技術研究所）

義江 龍一郎 (東京工芸大学)

吉川 優（大成建設（株）技術センター）

\section{参考文献}

1）中村良平, 宮下康一「ビル風問題の年譜」日本風工 学会誌, 第 43 巻 2 号, pp. 29-33, (2018)

2) 日本建築学会, 「市街地風環境予測のための流体数值 解析ガイドブック」, 日本建築学会, (2007)

3) Tominaga, Y., Mochida, A., Yoshie, R., Kataoka, H., Nozu, T., Yoshikawa, M., Shirasawa, T., "AIJ guidelines for practical applications of CFD to pedestrian wind environment around buildings", Journal of Wind Engineering and Industrial Aerodynamics, vol. 96, no. 10-11, pp. 1749-1761, (2008)

4) 大風翼, 菊本英紀, 小野浩己, 今野雅, 㣣間貴雅, 岸 田岳士, 中尾圭佑, 池谷直樹, 田畑侑一, 富永禎秀, LES による市街地風環境予測のためのガイドライン 策定に向けて その 1 1:1:2 単体建物周辺流れのべ ンチマーク テスト概要, 2017 年度日本建築学会大会 学術講演梗概集（中国）,pp.947-948, (2017)

5) 村上 周三, 岩佐 義輝, 森川 泰成, 「居住者の日誌に よる風環境調査と評価尺度に関する研究: 市街地低 層部における風の性状と風環境評価に関する研究 -III」, 日本建築学会論文報告集, 第 325 号, pp. 74-84, (1983)

6) 義江 龍一郎, 三浦 翔, 望月 政法,「風環境評価のた めの標準上空風データの整備に向けた領域気象モデ ルWRF の検証」, 日本風工学会論文集, 第 40 巻 4 号, pp. 113-122, (2015)

7) 日本建築学会, 都市の風環境評価と計画—ビル風か
ら適風環境まで」，日本建築学会, (2002)

8) 風工学研究所，「これだけは知っておきたい 新・ビ 儿風の知識」, 鹿島出版会, (1989)

9) 白澤 多一, 義江 龍一郎, 藤井 邦雄, 福留 伸高, 吉 田 真紗子，「住民参加型風環境マップの作成（その 1 ) 風環境マップの作成方法」, 日本建築学会大会 学 術講演梗概集, pp. 783-784, (2016)

10) 赤星 明紀, 猿川 明, 佐々木 亮治, 中村 修, 宮下 康一, 植松 康, 「超高層建物を有寸る都市域におけ る風観測結果とアンケート調査結果の関係 その 1 調査および検討の概要」, 日本建築学会大会学術講演 梗概集, pp. 151-152, (2017)

11) 日本ヒートアイランド学会 HP http://www.heat-island.jp/ThermalMap/about.html (2018.2)

12) 中村 修, 田村幸雄, 日比一喜, 徐曉達, 楊 慶山, 宮下 康一，「都市域 320 地点の歩行者レベルの風観 測データに基づく風安全指標の提案」, 日本風工学会 論文集, 第 41 巻 3 号, pp. 103-111, (2016)

13）日本風工学会 都市の風影響評価研究会 : 義江 龍一 郎, 富永 禎秀, 伊藤 真二, 岡田 創, 片岡 浩人, 喜々津 仁密, 佐々木 澄, 西村 宏昭, 野田 博, 林田 宏二, 宮下 康一, 山中 徹, 吉川 優, 「日最大瞬間風 速の超過確率に基づく風環境評価に用いるガストフ アクターの提案」, 日本風工学会論文集, 第 39 巻 2 号, pp. 29-39, (2014)

14）作田美知子，白澤多一，富永禎秀「自治体における ビル風に関する環境影響評価の実態調査」日本風工 学会誌, 第 43 巻 2 号, pp. 34-39, (2018)

15) 白澤 多一, 義江 龍一郎, 藤井 邦雄「住民参加型の 風環境調査事例」日本風工学会誌, 第 43 巻 2 号, pp. 40-44, (2018. 4)

16) 浅輪 貴史, 中大窪 千晶, 親川昭彦, 「スマホでつく る “暑さマップ”」日本風工学会誌, 第 43 巻 2 号, pp. 45-49, (2018) 